\section{Increase sensitivity to metals of hemocytes obtained from Mya arenaria collected at different distances from the shore}

\author{
G. Alix, ${ }^{1,2,3}$ A. Beaudry, ${ }^{1,2,3}$ \\ C. Brousseau-Fournier, ${ }^{1,2,3}$ M. Fortier, ${ }^{2}$ \\ M. Auffret, ${ }^{4}$ M. Fournier, ${ }^{1,2,3}$ \\ P. Brousseau $1,2,3$
}

${ }^{1}$ Parc de la rivière Mitis, Ste-Flavie, Québec, Canada; 'INRS-Institut-Armand-

Frappier, Laval, Québec, Canada;

${ }^{3}$ Université du Québec à Rimouski, Rimouski, Québec, Canada; ${ }^{4}$ Université de Bretagne Occidentale, Brest, France

\section{Introduction}

Biomarkers are used to measure the interaction between a stressor (physical, chemical or biological) and biochemical, cellular or physiological system, which initiate toxic events in organisms. Some biomarkers are good predictor of health in organism if the observed effects are irreversible or influences at higher level of biological organization. Among such biomarkers, organisms' health can be looked at by evaluating their immunocompetence. ${ }^{1-3}$ Bivalve molluscs are good sentinel species because they are sessile and they are exposed directly in contaminated aquatic environment. Moreover, being filter-feeding organisms, they have the ability to bioaccumulate contaminants from water, sediments and particles from which they feed. In bivalves, hemocytes circulating in the hemolymph represent a key component of their immune system. ${ }^{4-6}$ One appropriate tool to evaluate their immunocompetence is through the evaluation of cell viability ${ }^{1,7}$ and phagocytosis activity. In this study, the immunological response of softshell clams (Mya arenaria) collected at two distances from the shore was studied. Indeed, intertidal clams have to cope to anoxic periods and temperature changes, which thereby could increase their susceptibility towards contaminants. The objective is to determine whether clam's ability to resist to the toxic effects of various metals could be modulated by the distance between shore and sites collection, reflecting various time they spent in low tide.

\section{Materials and Methods}

\section{Animals}

Soft-shell clams were collected, at low tide at
3 sites (Jardins, Motel and Anse) and at 2 different distances from the shore (upper shore, middle shore) corresponding to circa $5 \mathrm{~h}$ and 2 $\mathrm{h}$ exposure to air in Mitis Bay (48 $40^{\prime} \mathrm{N}$, $68^{\circ} 00^{\prime} \mathrm{W}$ ). The first site is our reference clean site, and the others two are sites intensively managed and numerous human activities were observed. Upon arrival to the laboratory, all bivalves were transferred in containers with sea water and algae maintained at $4^{\circ} \mathrm{C}$ for $24 \mathrm{~h}$ before starting the experiment.

\section{Collection of hemocytes and expo- sure to metals}

Hemolymph was extracted from the posterior adductor muscle using $3 \mathrm{~mL}$ syringe and 23 $\mathrm{G}$ needle. The metals used in this study were mercuric chloride $\left(\mathrm{HgCl}_{2}\right)$, lead chloride $\left(\mathrm{PbCl}_{2}\right)$ and cadmium chloride $\left(\mathrm{CdCl}_{2}\right)$ (Aldrich Chemical Company, Milwaukee, WI, USA). Toxicants were all prepared at $0.1 \mathrm{M}$ in deionised water. These stock solutions were made fresh for each experiment. Working solutions of each metal, ranging from $10^{-3} \mathrm{M}$ to $10^{-9}$ $\mathrm{M}$, were prepared by serial dilutions of stock solutions with hemolymph. Controls were obtained by incubating the cells with deionised water only. The cells were incubated at $20^{\circ} \mathrm{C}$ for 3 hours in 96 -well plate. Then, fluorescently labeled latex FluoSpheres (Molecular Probes Inc., Eugene, OR, USA) were added in excess for $18 \mathrm{~h}$ at $20^{\circ} \mathrm{C}$ in the dark.

\section{Determination of viability and phagocytosis}

The viability was determined by flow cytometry using a Guava PCA flow cytometer and a Viacount kit (GuavaTechnologies, Hayward, CA, USA) according to the supplier's instructions. In addition, the mean percent viable cell was higher than $80 \%$ at the beginning of the in vitro exposure. Phagocytosis was monitored according to the method developed in our laboratory. ${ }^{8}$ At the end of the incubation, the supernatant was delicately removed by decantation. Then the cells were fixed with $0.5 \%$ formalin in phosphate buffered saline. Phagocytosis was measured by flow cytometry with a FACScan (Becton Dickinson, San Jose, CA, USA) whereas hemocyte populations were defined based on their forward and right angle scatter properties. A total of 3000 events were acquired for each sample and percentage of cells which have engulfed one bead and more (activity) and three beads and more (efficacy) were determined as fluorescence frequency distribution on FL1. Data collection and analysis were performed with LYSIS-II program.

\section{Statistical treatments}

The results were analyzed by ANOVA followed by a Tukey's test for pairwise comparisons. Statistical analyses were performed
Correspondence: Michel Fournier, Institut National de la Recherche Scientifique-InstitutArmand-Frappier (INRS-IAF) 531 boul. des Prairies, Laval, Quebec, Canada H7V 1 B7.

E-mail: michel.fournier@iaf.inrs.ca

Key words: hemocytes, sensitivity to metals, $M y a$ arenaria.

Conference presentation: part of this paper was presented at the ECOBIM meeting, 2013 May, Montréal, Quebec, Canada.

This work is licensed under a Creative Commons Attribution NonCommercial 3.0 License (CC BYNC 3.0).

(C) Copyright G. Alix et al., 2013

Licensee PAGEPress, Italy

Journal of Xenobiotics 2013; 3(s1):e11

doi:10.4081/xeno.2013.s1.e11

using SigmatSat (version 3.5) Significance was set at $\mathrm{P} \leq 0.05$.

\section{Results}

Results of phagocytosis activity and efficacy obtained from clams collected upper shore and middle shore at the Motel site, following an in vitro exposure to mercuric chloride, are shown in Figure 1. Although there were no significant differences between upper shore and middle shore locations in the controls. However, hemocytes obtained from clams collected in upper shore were more sensitive to the toxic effect of mercury as shown by a significant suppression of phagocytic activity as well as efficacy for exposure to mercury at concentrations ranging from $10^{-8}$ up to $10^{-3} \mathrm{M}$.

A summary of the results of the phagocytosis obtained at the other two sites for $\mathrm{Hg}$ as well as results obtained with cadmium and lead, in which we compared upper to middle shore, are provided in Table 1. With the exception of lead at Motel site, there is a general trend towards significant decrease of phagocytic activity as well as efficacy in clams collected in upper shore in the same range of concentrations for Motel and Anse sites. For the Jardins site, which is our reference clean site, significant reduction of phagocytosis was also obtained with the three metals in clams collected in upper shore. However, the suppression was observed at higher metal concentrations $\left(10^{-5} \mathrm{M}\right.$ instead of $\left.10^{-8} \mathrm{M}\right)$.

\section{Discussion and Conclusions}

It is already well documented that soft-shell 


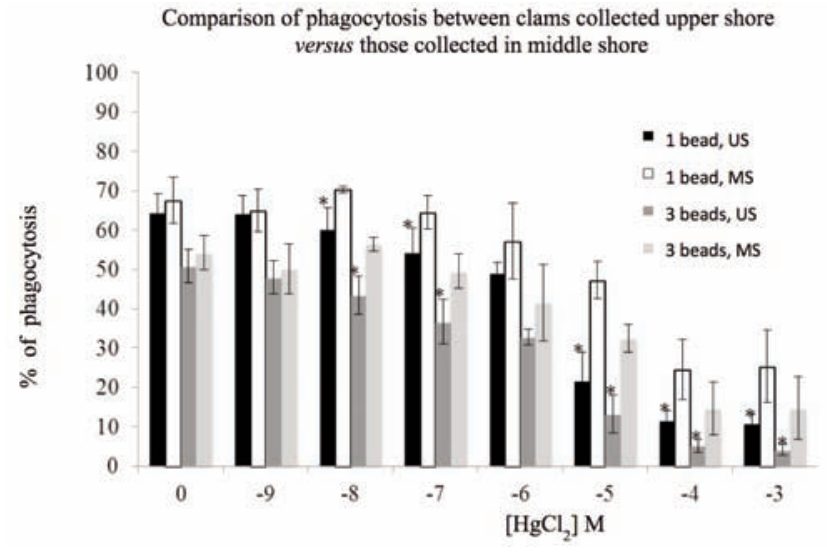

Figure 1. Phagocytosis activity (1 bead and more) and efficacy (three beads and more) of hemocytes obtained from Mya arenaria collected from middle (MS) and upper shore (US) at the Motel site in Metis Bay. Hemocytes were exposed to mercuric chloride at concentrations ranging from 0 up to 10-3 M. A significant suppression of phagocytic activity as well as efficacy was observed for hemocytes collected in the upper shore. ${ }^{*} \mathrm{P} \leq 0.05$. $\mathrm{HgCl} 2$, mercuric chloride.

clams immunocompetence is altered by pollution such as $\mathrm{Hg}$, but this response could be also modulated by environmental stresses such as temperature, cyclic or tidal exposure to air ${ }^{9}$ and pathogens. ${ }^{1,10}$ In the present study, we wanted to evaluate the impact of exposure to air, during tidal events, on the sensitivity of hemocytes to metal exposures. This is the first time that impact of tides and exposure to air at low tide is shown in Mya arenaria. Upper shore soft-shell clams undergo more environmental stress since they are exposed for longer period to the air (see Materials and Methods section) than clams from middle shore. This could explain at least in part why those soft-shell clams have weaker immune system when exposed to metals. A possible explanation for this is that clams exposed to longer air-times endure more anoxic stress and bacteria could proliferate more when the temperature increases. We have found that hemocytes obtained from soft-shell clams, which are exposed to greater periods to air, are more sensitive to the toxic effects of metals. If this holds true, these clams would be the first to disappear upon pollution stress.
Table 1. Summary of the results obtained for phagocytic activity and efficacy when results obtained in clams collected upper shore were compared to the clams collected at middle shore. Throughout the experiment, with the exception of lead at the Motel site, results obtained in clams collected in the upper shore were significantly lower than results obtained in clams collected in the middle shore.

\begin{tabular}{lccc} 
& $\mathrm{CdCl}_{2}$ & $\mathrm{HgCl}_{2}$ & $\mathrm{PbCl}_{2}$ \\
Jardins & $\downarrow$ & $\downarrow$ & $\downarrow$ \\
Motel & $\downarrow$ & $\downarrow$ & - \\
\hline Anse & $\downarrow$ & $\downarrow$ & $\downarrow$
\end{tabular}

$\mathrm{CdCl}_{2}$, cadmium chloride; $\mathrm{HgCl}_{2}$, mercuric chloride; $\mathrm{PbCl}_{2}$, lead chloride.

\section{References}

1. Gagné F, Blaise C, Pellerin J, Fournier M, Gagnon C, Sherry J, et al. Impacts of pollution in feral Mya arenaria populations: The effects of clam bed distance from the shore. Sci Total Environ 2009;407:5844-54.

2. Perceval 0, Couillard Y, Penil-Alloul B, Giguère A, Campbell PGC. Metal-induced stress in bivalves living along a gradient of Cd contamination: relating sub-cellular metal distribution to population-level responses. Aquat Toxicol 2004;69:327-45.

3. Gagné F, Blaise C, Pellerin J, Fournier M, Durand MJ, Talbot A. Relationships between intertidal clam population and health status of the soft-shell clam Mya arenaria in the St. Lawrence Estuary and Saguenay Fjord (Québec, Canada). Environ Int 2008;34:30-42.

4. Sauvé S, Brousseau P, Pellerin J, Morin Y, Senécal L, Goudreau P, et al. Phagocytic activity of marine and freshwater bivalves: in vitro exposure of hemocytes to metals (Ag, Cd, Hg and $\mathrm{Zn}$ ). Aquat Toxicol 2002; 58:189-200.

5. Cheng TC. Biochemical and ultrastructural evidence for the double role of phagocy- tosis in molluscs: defense and nutrition. Comparative Pathobiol 1977;3:21-30.

6. Adema CM, Van der Knapp WPW, Sminia T. Molluscan hemocyte-mediated cytotoxicity: The role of reactive oxygen intermediates. Rev Aquat Sci 1991;4:201-23.

7. Gauthier-Clerc S, Pellerin J, Fournier M, Amiard JC. Immunological and biochemical responses in Mya arenaria (Mollusca: Bivalvia) exposed in vivo to estradiol-17 . Comp Biochem Physiol 2006;144C:228-34.

8. Brousseau P, Pellerin J, Morin Y, Cyr D, Blakley B, Boermans H, et al. Flow cytometry as a tool to monitor the disturbance of phagocytosis in the clam Mya arenaria hemocytes following in vitro exposure to heavy metals. Toxicology 2000;142:145-56.

9. Beaudry A, Brousseau-Fournier C, Alix G, Fortier M, Auffret M, Brousseau P, et al. Influence of tidal stress on the immunocompetence of hemocytes in soft-shell clam (Mya arenaria). J Xenobiotics 2013;3 (s1):e13.

10. Tremblay R, Pellerin-Massicotte J. Effect of the tidal cycle on lysosomal membrane stability in the digestive gland of Mya arenaria and Mytilus (L). Comp Biochem Physiol 1997;117A:99-104. 